\title{
DÜBLIN
}

Technological University Dublin

ARROW@TU Dublin

2007-01-01

\section{Printed Band-rejection UWB Antenna with H-shaped Slot}

\author{
Xiulong Bao \\ Technological University Dublin, xiulong.bao@tudublin.ie \\ Max Ammann \\ Technological University Dublin, max.ammann@tudublin.ie
}

Follow this and additional works at: https://arrow.tudublin.ie/engschececon

Part of the Electrical and Computer Engineering Commons

\section{Recommended Citation}

Bao, X. \& Ammann, M. (2007) Printed band-rejection UWB antenna with $\mathrm{H}$-shaped slot. IWAT '07:International Workshop on Antenna Technology: Small and Smart Antennas Metamaterials and Applications,Cambridge, 21-23 March, 2007, doi:10.1109/IWAT.2007.370139

This Conference Paper is brought to you for free and open access by the School of Electrical and Electronic Engineering at ARROW@TU Dublin. It has been accepted for inclusion in Conference papers by an authorized administrator of ARROW@TU Dublin. For more information, please contact arrow.admin@tudublin.ie, aisling.coyne@tudublin.ie,gerard.connolly@tudublin.ie. Funder: Science Foundation Ireland 


\title{
Printed Band-Rejection UWB Antenna with H-shaped Slot
}

\author{
X.L. Bao, M. J. Ammann• \\ Centre for Telecommunications Value-chain Research, \\ School of Electronic \& Communications Engineering, \\ Dublin Institute of Technology, Kevin Street, Dublin 8, Ireland
}

\section{INTRODUCTION}

The development of the high data rate wireless communication systems, has placed significant demands on antenna designers, in particular, the requirement for smaller elements with broader bandwidths. In recent years, ultrawide band (UWB) antennas have received increased attention. Planar UWB monopole antennas with rectangular, circular, elliptical and triangular shapes patch have been reported [1-3]. It is also necessary for UWB systems to minimize in-band interference effects, within the UWB band (3.1GHz-10.6GHz). In particular, the growth of IEEE 802.11a wireless LAN in the the frequency-band $5.15 \mathrm{GHz}-5.825 \mathrm{GHz}$, has increased.. Therefore, antennas providing reject notch function are becoming necessary. Recently, some antennas with notch-band function have been discussed [4-5]. In this paper, a novel UWB antenna with notch-band frequency is studied. Effects of the various parameters for antenna performances are also discussed. An optimized compact UWB antenna with notch-frequency function is fabricated and experimentally examined. The measured results show the proposed UWB antenna can achieve a return loss greater than lodb over an ultrawide bandwidth, of $9.8 \mathrm{GHz}$, from $2.97 \mathrm{GHz}$ to $12.77 \mathrm{GHz}$ with a tunable notch-frequency band of $5.15 \mathrm{GHz}$ to $5.825 \mathrm{GHz}$.

\section{SIMULATED RESULTS FOR THE PRINTED MONOPOLE ANTENNA WITH SLOT PATCH}

In order to design the proposed UWB antenna with the narrow band-rejected frequency, the rectangular patch with a H-shape slot is employed, as shown in Figure 1. Using the optimized parameters for the antenna, the proposed antenna dimensions are selected as $L=28 \mathrm{~mm}, W g=30 \mathrm{~mm}, W I=12 \mathrm{~mm}, L 1=16.5 \mathrm{~mm}, G w=1.5 \mathrm{~mm}, L 2=4 \mathrm{~mm}$ and $W 2=3 \mathrm{~mm}$. The substrate is a Taconic RF- 35 of relative permittivity 3.5 and the thickness is $1.52 \mathrm{~mm}$. The effects of the width and length of $\mathrm{H}$ slot for narrow rejected-band function are analyzed below.

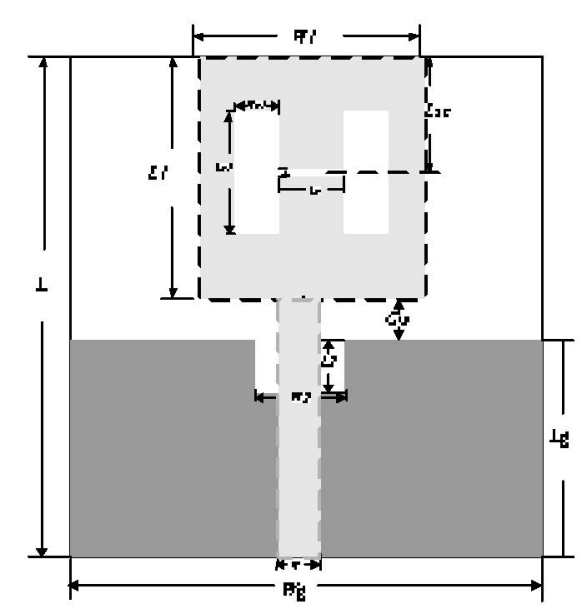

Figure 1 The geometry of the proposed UWB antenna with notch-frequency function 


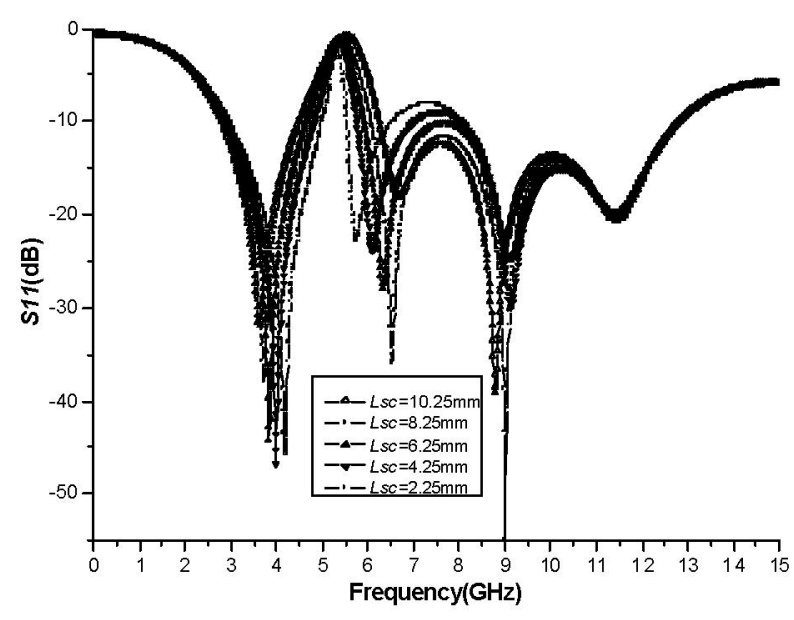

Figure 2 Comparison of the return loss for the proposed antennas with different $L s c$

\section{Effect of slot width $W s$}

Figure 3 shows return loss with difference $W_{\mathrm{s}}$ dimensions for $L s I=4 \mathrm{~mm}, W s I=2.2 \mathrm{~mm}, L s c=2.25 \mathrm{~mm}, W s=0.3 \mathrm{~mm}$ and $L s=4 \mathrm{~mm}$. It is noted that the centre frequency of the rejected-band will increase as the slot width $W$ s increases, and the return loss at the centre frequency decreases slightly with increasing slot $W s$.

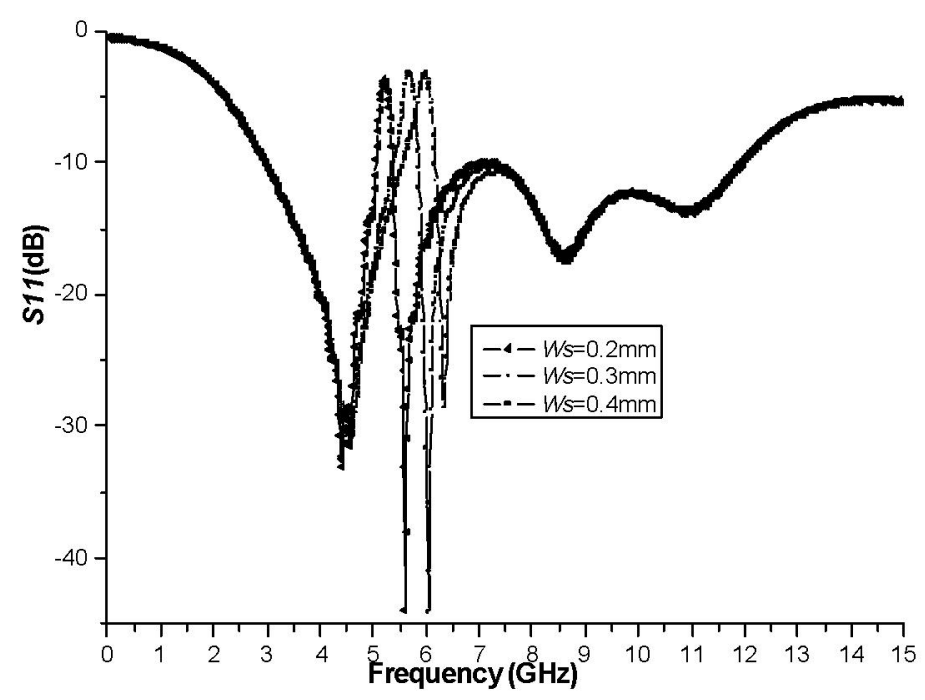

Figure 3 Comparison of the return loss for the proposed antennas with different $W S$

\section{Effects of the slot $W s I$ and $L s I$}

Figure 4 and Figure 5 illustrate the return loss for different values of $W s I$ when $L s I=4 \mathrm{~mm}, L s c=2.25 \mathrm{~mm}, W s=0.3 \mathrm{~mm}$ and $L s=4 \mathrm{~mm}$ and also for different values of $L s I$ when $W s I=2.5 \mathrm{~mm}, L s c=2.25 \mathrm{~mm}$ and $W s=0.3 \mathrm{~mm}$. It is found that the centre frequency of rejected-band increases with increase of slot width Ws1 and also with increase of slot length $L s 1$. , The optimumlength and width are $W s l=2.5 \mathrm{~mm}$ and $L s l=4 \mathrm{~mm}$. 


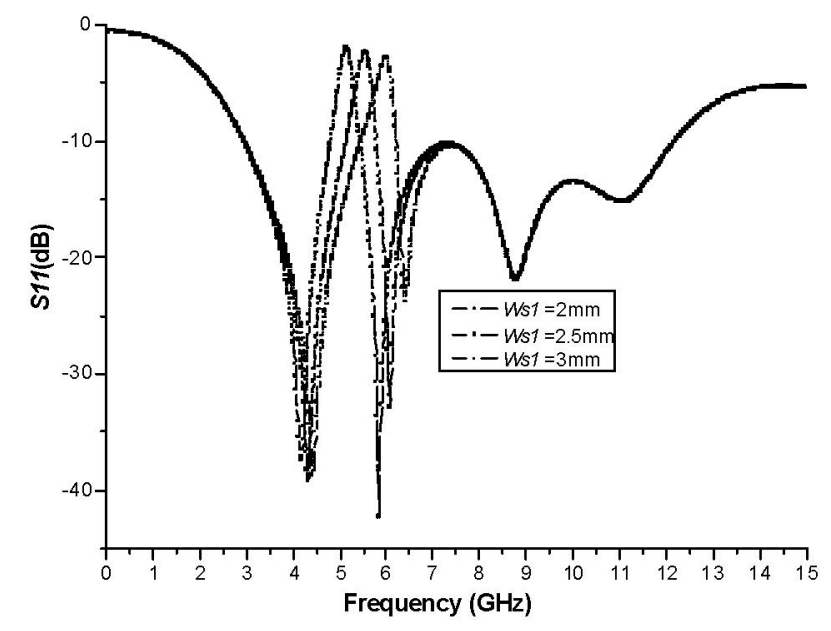

Figure 4 Comparison of the return loss for the proposed antennas with different $W_{s} 1$

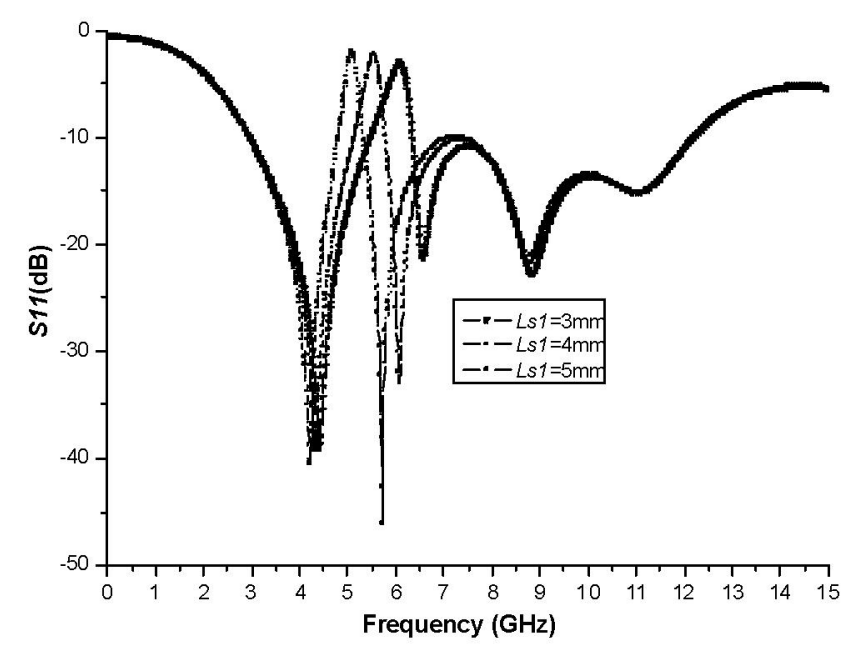

Figure 5 Comparison of the return loss for the proposed antennas with different $L s 1$

\section{MEASUREMENT OF RETURN LOSS FOR THE PROPOSED ANTENNAS}

A compact and ultrawideband printed antenna with a narrow notch-frequency function is designed and fabricated based on the simulated results in previous sections. It is printed on the Taconic substrate of relative permittivity 3.5, thickness of $1.52 \mathrm{~mm}$ and loss tangent of 0.0018 . Its optimized dimensions are as follows: $L=28 \mathrm{~mm}, W g=30 \mathrm{~mm}$, $L I=16.5 \mathrm{~mm} W I=12 \mathrm{~mm}, L 2=4 \mathrm{~mm}, W 2=3 \mathrm{~mm}, G w=1.5 \mathrm{~mm}, L g=10 \mathrm{~mm}$, and the $50 \mathrm{ohm}$ microstrip line width $w$ is $3.5 \mathrm{~mm}$. The parameters of the H-shaped slot are selected to be $L s c=2.25 \mathrm{~mm}, L s l=4 \mathrm{~mm}, W s 1=2.5 \mathrm{~mm}, L s=4 \mathrm{~mm}$ and $W_{s}=0.3 \mathrm{~mm}$. Figure 6 illustrates the simulated and measured results of return loss for the proposed antenna. The $10 \mathrm{~dB}$ return loss impedance bandwidth is about $9.8 \mathrm{GHz}$, from $2.97 \mathrm{GHz}$ to $12.77 \mathrm{GHz}$ with a narrow notch-band of $5.15 \mathrm{GHz}$ to $5.825 \mathrm{GHz}$. The measured boresight gains in the $\mathrm{H}$ plane are shown in Figure 7, which have a large drop in the notch-frequency band.

\section{CONCLUSIONS}

In this paper, a parametric study of the slotted planar monopole is made with regard to the notch frequency and 
impedance bandwidth. According to the above analysis, the compact and optimized ultrawideband antenna with a tunable notch-frequency band is designed, fabricated and measured.

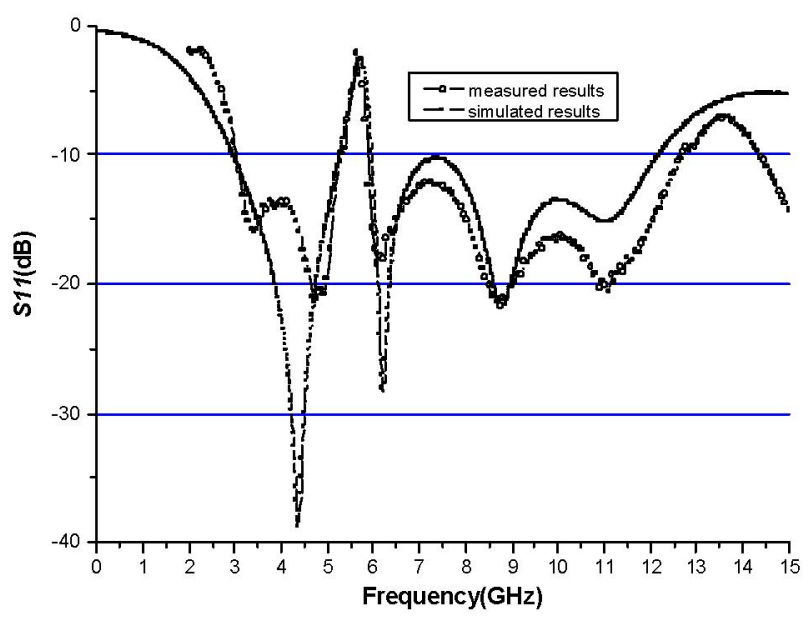

Figure 6 Comparison of the measured and simulated results for the proposed antenna

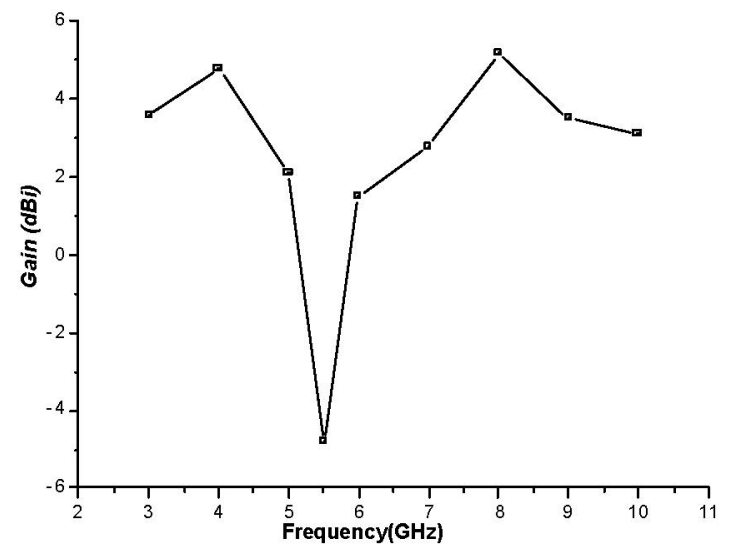

Figure 7 The measured boresight gain against frequency for proposed antenna

\section{ACKNOWLEDGEMENT}

This work is supported by Science Foundation Ireland.

\section{REFERENCES}

[1] C.C.Lin, Y.C.Kan,L.C.Kuo,H.R.Chuang, A Planar Triangular Monopole Antenna for UWB Communication, IEEE Microwave and Wireless Components Letters, Vol.15,No.10, Oct. 2005, pp.624-626.

[2] M.J.Ammann, M.John, Optimum Design of the Printed Strip Monopole, IEEE Antennas and Propagation Magazine, Vol.47, No.6, Dec. 2005, pp.59-61.

[3] J.Liang, L.Guo, C.C.Chiau, X.Chen, C.G.Parini, Study of CPW-fed Circular Disc Monopole Antenna for Ultra Wideband Applications IEE Proc. Microw. Antennas Propag, Vol.152, No.6, Dec. 2005, pp.520-526.

[4] W.C.Liu, P.C.Kao, CPW-Fed Triangular Antenna with a Frequency-Band Notch Function for Ultra-Wideband Application, Microwave and Optical Technology Letters, Vol.48,No.6, June 2006, pp.1032-1035.

[5] K.Chung, J.Kim, J.Choi, Wideband Microstrip-Fed Monopole Antenna Having Frequency Band-Notch Function, IEEE Microwave and Wireless Components Letters, Vol.15,No.11,Nov. 2005, pp.766-768. 